\title{
NOTICOMUNITARIA
}

\section{APERTURA DEL CURSO DE ESTIMULACIÓN TEMPRANA}

Ángela María Hernández§§§§

En el Centro Médico Corpas Lisboa, se dio inicio el pasado 28 de enero del presente año, al curso de Estimulación Temprana, el cual está dirigido a las familias que tienen hijos entre los 4 y 18 meses de edad.

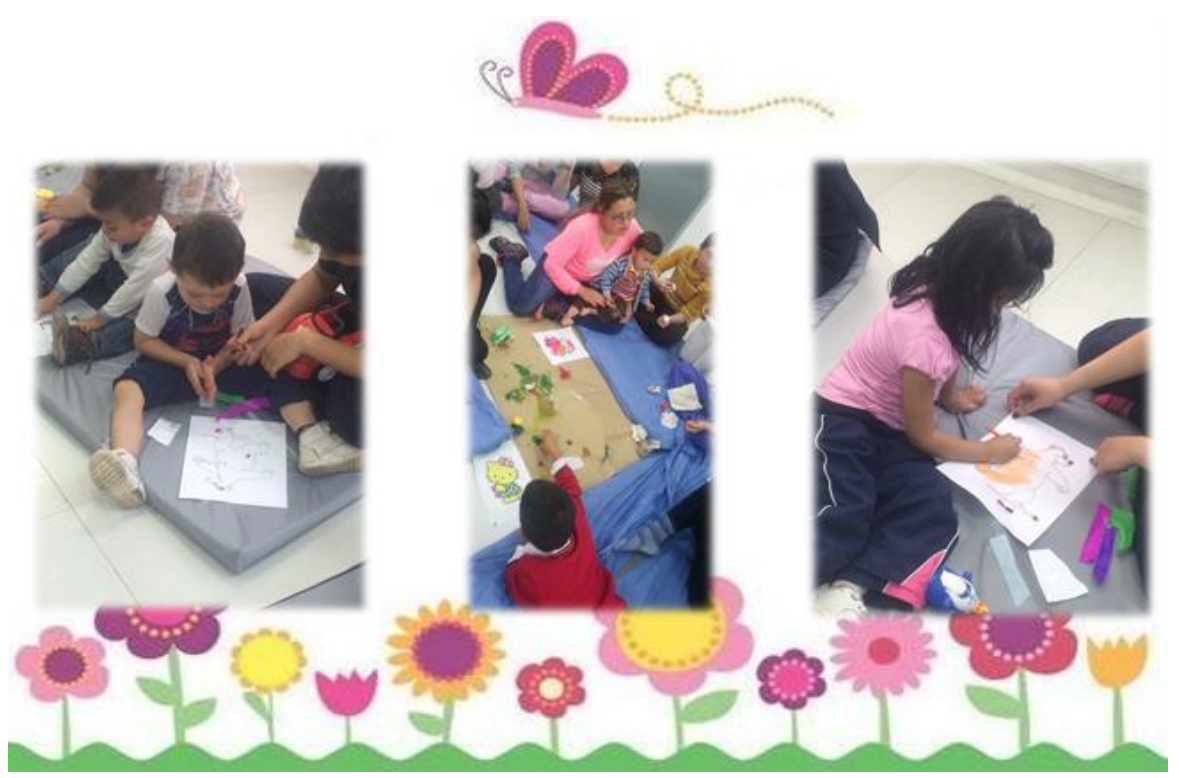

Esperamos que este tipo de iniciativas de educación comunitaria sean de gran provecho para la población y que cada día se vínculen más familias al centro médico comunitario.

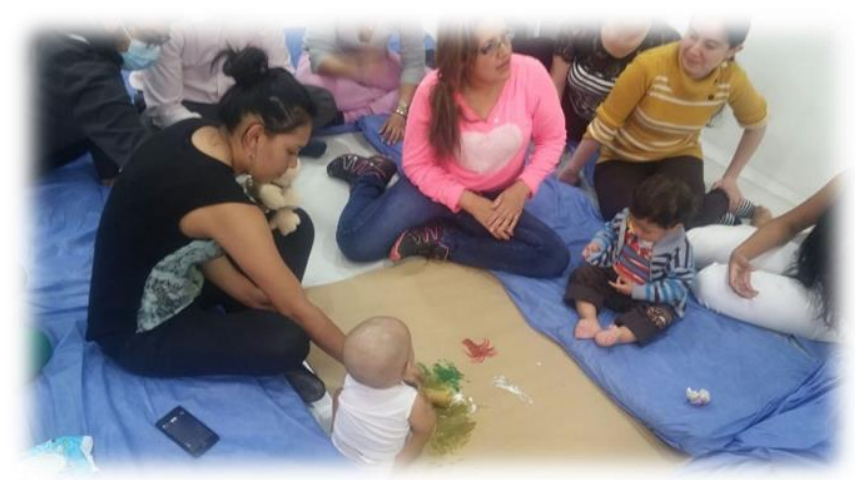

§§§§ MD, Magíster Educación. Especialista en Salud Familiar. Profesor Agregado FUJNC angela.hernandez@juanncorpas.edu.co 